\title{
Effect of nitrofen in the final stages of development of the diaphragm muscle in rats $^{1}$
}

\author{
Efeito do nitrofen na fase final do desenvolvimento da musculatura do diafragma em ratos
}

\author{
Frances Lilian Lanhellas Gonçalves ${ }^{1}$, Fábio Santana de Oliveira" ${ }^{\mathrm{II}}$, Augusto Frederico Schmidt" ${ }^{\mathrm{III}}$, Luís Antônio Violin Dias \\ Pereira $^{\mathrm{IV}}$, Rodrigo Melo Gallindov , Rebeca Lopes Figueira ${ }^{\mathrm{VI}}$, Lourenço Sbragia ${ }^{\mathrm{VII}}$
}

${ }^{\mathrm{I}} \mathrm{PhD}$, Fellow Post-Doctoral degree, Division of Pediatric Surgery, Department of Surgery and Anatomy, School of Medicine of Ribeirao Preto, University of Sao Paulo (FMRP-USP). Ribeirao Preto - SP, Brazil. Surgical and histological procedures, acquisition of data, data analysis and manuscript writing.

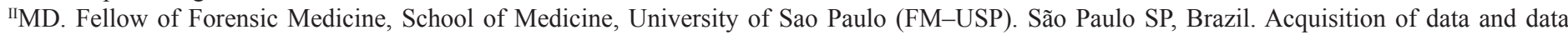
analysis.

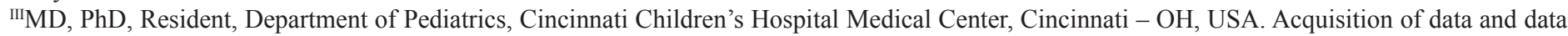
analysis.

${ }^{\mathrm{IV}} \mathrm{MD}, \mathrm{PhD}$, Associate professor, Department of Histology and Embryology, State University of Campinas (UNICAMP). Campinas - SP, Brazil. Histological procedures and critical revision.

${ }^{v}$ MD, Fellow Master degree, Division of Pediatric Surgery, Department of Surgery and Anatomy, School of Medicine of Ribeirao Preto, University of Sao Paulo (FMRP-USP). Ribeirao Preto - SP, Brazil. Acquisition of data and data analysis.

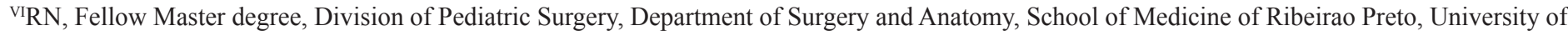
Sao Paulo (FMRP-USP). Ribeirao Preto - SP, Brazil. Acquisition of data.

${ }^{\mathrm{VII}} \mathrm{MD}, \mathrm{PhD}$, Associate professor, Division of Pediatric Surgery, Department of Surgery and Anatomy, School of Medicine of Ribeirao Preto, University of Sao Paulo (FMRP-USP). Ribeirao Preto - SP, Brazil. Mentor, conception and design of study, manuscript writing and critical revision.

\section{ABSTRACT}

PURPOSE: To evaluate the expression of myosin in muscle fibers of the diaphragm in experimental congenital diaphragmatic hernia (CDH).

METHODS: Fetuses of pregnant rats were divided into four groups: External Control (EC), composed of non-manipulated rats; Nitrofen, composed of pregnant rats that received $100 \mathrm{mg}$ of nitrofen (2,4-dichloro-4'nitrodiphenyl ether) diluted in olive oil on gestational day (GD) 9.5, whose fetuses developed $\mathrm{CDH}(\mathrm{N}+)$ or not $(\mathrm{N}-)$, and Olive Oil Placebo $(\mathrm{OO})$, composed of pregnant rats that received the oil on the same GD. The fetuses were collected on GD 18.5, 19.5, 20.5 and 21.5 (term = 22 days). We obtained body weight (BW) and photographed the diaphragm area (DA), hernia area (HA) and subsequent calculated the HA/DA ratio in N+ group. Samples of Diaphragm muscle were processed for histological staining with H/E and immunohistochemistry (IHQ) for myosin.

RESULTS: The fetuses of $\mathrm{N}$ - and $\mathrm{N}+$ groups had decreased BW and DA compared to EC and OO groups ( $\mathrm{p}<0.001)$. HA was decreased on GD 18.5 compared to $21.5(\mathrm{p}<0.001)$ and the HA/DA ratio showed no difference. IHQ showed decreased expression of myosin in nitrofen groups.

CONCLUSION: CDH induced by nitrofen model contributes to the understanding of muscularization in the formation of the diaphragm where the myosin expression is decreased.

Key words: Hernia. Diaphragmatic. Diaphragm. Abnormalities, Drug-Induced. Myosins. Rats.

\section{RESUMO}

OBJETIVO: Avaliar a expressão da miosina na muscularização do diafragma na hérnia diafragmática congênita (CDH) experimental. MÉTODOS: Fetos de ratas foram divididos em quatro grupos: Controle Externo (EC), composto de ratas não manipuladas; Nitrofen, composto de ratas que receberam $100 \mathrm{mg}$ de nitrofen (2,4-dicloro-4'nitrodifenil éter) diluído no azeite no dia de gestação (GD) 9.5, cujos fetos desenvolveram $\mathrm{CDH}(\mathrm{N}+)$ ou não $(\mathrm{N}-)$ e Placebo óleo de oliva $(\mathrm{OO})$, composto de ratas que ingeriram apenas óleo no mesmo GD. Os fetos foram coletados com 18,5, 19,5, 20,5 e 21,5 GD (termo = 22 dias). Foi obtido o peso corporal (BW) e tiradas fotografias da área do diafragma (DA), da hérnia (HA) e calculada a relação HA/DA no grupo $\mathrm{N}+$. Amostras de diafragmas foram processadas histologicamente para coloração com $\mathrm{H} / \mathrm{E}$ e imunohistoquímica.

RESULTADOS: Os fetos dos grupos N- e N+ tiveram BW e DA diminuídos em relação aos grupos EC e OO (p<0.001). Só houve diferença na HA entre os GD 18.5 e 21.5 (p<0.001) e a relação HA/DA não mostrou diferença entre os grupos. A imunohistoquímica mostrou menor expressão de miosina nos grupos que receberam nitrofen.

CONCLUSÃO: O modelo de CDH induzida por nitrofen contribui para entender a muscularização na formação do diafragma onde a expressão da miosina está diminuída.

Descritores: Hérnia Diafragmática. Diafragma. Anormalidades Induzidas por Medicamentos. Miosinas. Ratos. 


\section{Introduction}

Congenital diaphragmatic hernia $(\mathrm{CDH})$ is a malformation of the diaphragm due to a defect in the development of the pleuroperitoneal membranes, which creates an opening in the dorsolateral region that occurs on the left side in $85 \%$ of the time $^{1}$. CDH occurs approximately in 1 in every 3000 live births ${ }^{2}$, totaling about $8 \%$ of major congenital anomalies, with mortality rates ranging from $62 \%$ to $79 \%{ }^{3}$. This high mortality is mainly attributed to pulmonary hypoplasia and hypertension, especially due to the biochemical and structural immaturity that occurs secondary to intrathoracic occupation by abdominal viscera ${ }^{4}$.

The diaphragm muscle is embryologically derived from the septum transversum, the pleural peritoneal membranes (PPM) and the inner portion of the abdominal wall. The PPMs fuse with the dorsal mesentery of the esophagus and the septum transversum. After that, they complete segmentation of the thoracic and abdominal cavities. The evidences indicate that the PPMs are the largest, if not the only structure responsible for the development of the diaphragm muscles ${ }^{5}$.

As soon as the primary structure of muscle diaphragm is completely formed, it occurs the migration of muscle precursor cells. These cells originate from the embryo somites, proliferate and differentiate into myocytes mainly due to expression of alphaactin and myosin heavy chains, which together, form cross-bridges and rise the muscle contractility ${ }^{6}$.

The first toxicological model of $\mathrm{CDH}$ emerged from the observation that retinol deficient mice embryos develop $\mathrm{CDH}^{7}$. Among teratogens that are capable of inducing the defect, the most extensively studied and characterized model is the one utilizing the herbicide nitrofen (2,4-dichloro-4'nitrodiphenyl ether), that can cause left side $\mathrm{CDH}$ in $42 \%$ of the rat litter $^{8}$.

Nitrofen acts during the development of the diaphragm, and although the biochemical mechanism of this drug isn't well understood it can be partially explained by disruption of the retinoic acid pathway. On the other hand, the primary mechanism of its teratogenesis at the PPMs of mouse embryos is caused by decreasing proliferation of mesenchymal cells in the developing diaphragm ${ }^{9}$.

In order to contribute to the understanding of the development of the diaphragm and $\mathrm{CDH}$ we evaluated the progression of the dimensions of the defect and the expression of myosin during late gestation in experimental $\mathrm{CDH}$.

\section{Methods}

This study was approved by the Ethics Committee on Animal Research of School of Medicine of Ribeirao Preto of University of Sao Paulo -USP (research project $n^{\circ}$ 043/2011). Sprague-Dawley rats were kept under a controlled day-night cycle with ad libitum food and water supply. The animals were mated during the night cycle and the next day, after vaginal smear confirmed sperm presence, was considered as gestational day (GD) 0 (term $=22$ days).

\section{Experimental groups}

Pregnant rats were divided into three experimental groups and its fetuses into four groups, each group with 12 fetuses per gestational age:

1. External Control (EC): Pregnant rats were submitted to laparotomy (cesarean) on GD 18.5, 19.5, 20.5 and 21.5 for the collection of fetuses.

2. Olive Oil Placebo (OO): Pregnant rats received $1 \mathrm{ml}$ of olive oil by gavage on GD 9.5 and were submitted to laparotomy (cesarean) on GD 18.5, 19.5, 20.5 and 21.5 for collection of fetuses.

3. Nitrofen without $\mathrm{CDH}(\mathrm{N}-)$ : Pregnant rats were given $100 \mathrm{mg}$ of nitrofen (Maybridge, Cambridge, UK), dissolved in $1 \mathrm{ml}$ of olive oil by gavage on GD 9.5 and were submitted to laparotomy (cesarean) on GD 18.5, 19.5, 20.5 and 21.5 for the collection of fetuses. The group consisted of fetuses that did not develop CDH.4. Nitrofen with $\mathrm{CDH}(\mathrm{N}+)$ : Pregnant rats were given $100 \mathrm{mg}$ of nitrofen (Maybridge, Cambridge, UK) dissolved in $1 \mathrm{ml}$ of olive oil by gavage on GD 9.5 and were submitted to laparotomy (cesarean) on GD 18.5, 19.5, 20.5 and 21.5 for the collection of fetuses. The group consisted of fetuses that developed $\mathrm{CDH}$.

\section{Samples collection}

On GD 18.5, 19.5, 20.5 and 21.5, the rats were anesthetized and submitted to laparotomy. The fetuses were extracted from the uterus, weighted (Body weight - BW) and then sacrificed by decapitation.

\section{Photographic documentation of the diaphragm}

After disection of the abdominal wall with removal of the viscera in six fetuses per group for each GD, we used a digital 
camera (Nikon Coolpix p500) with a tripod setting the focal length of $50 \mathrm{~cm}$, with the plane of the lens parallel to the transverse plane of the fetus, allowing the photograph of the diaphragm area (DA). We used a square of $100 \mathrm{~mm}^{2}$ as a standard measure on the left side of the diaphragm during the photograph. In fetuses with $\mathrm{CDH}$ the hernia area (HA) was measured to further verify the hernia to total diaphragm area ratio (HA/DA). Then, the areas obtained were converted from pixel units to mm using Image Pro Plus 4.5.1.22 (Media Cybernetics) software.

\section{Specimen processing and histological analysis}

Six fetuses from each group were decapitated and fixed in $10 \%$ formalin. After histological processing axial sections of $5 \mu \mathrm{m}$ were obtained. For basic histological analysis, the diaphragms were stained with hematoxylin and eosin $(\mathrm{H} / \mathrm{E})$ and for immunohistochemistry analysis the slides were not stained.

\section{Immunohistochemistry}

Three slides per fetus were treated with sodium borate (0.1M, pH 7.4) for one hour at room temperature, followed by sodium citrate $(0.01 \mathrm{M}, \mathrm{pH} 6.0)$ for antigen exposition. Then they were treated with $1 \% \mathrm{H}_{2} \mathrm{O}_{2}$ and washed in PBS $(0.01 \mathrm{M}, \mathrm{pH}$ 7.4). Sections were incubated with blocking solution of bovine serum albumin (BSA) $1 \%$ for $1 \mathrm{~h}$ at room temperature to block nonspecific binding sites. Sections were incubated with antimyosin (Ab27718, $\mathrm{Abcam}^{\circledR}$, UK) diluted 1:200 in 0.1\% PBS at $4^{\circ} \mathrm{C}$ overnight. After washing, sections were incubated with biotin-conjugated anti-rabbit $\operatorname{IgG}(1: 200$ in $1 \% \mathrm{BSA})$ for $1 \mathrm{~h}$ at room temperature. As negative controls we omitted the primary antibody. For visualization of histochemical reaction we used the Vectastain ABC kit (Vector Laboratories, Burlingame, CA) and $\mathrm{DAB}$ (3,3'-diaminobenzidine tetrahydrochloride hydrated, Sigma-Aldrichm St Louis, MO). Sections were counterstained with Harris Hematoxylin and mounted.

\section{Statistical analysis}

Morphometrical data was described as means \pm standard deviation (SD) and compared by ANOVA with Tukey's posttest using GraphPad Prism 3.02. A p value $<0.05$ difference was considered significant.

\section{Results}

Body weight

In all groups there was a progressive increase of BW with increasing gestational age. However, we noted that the fetuses of $\mathrm{N}$ - and $\mathrm{N}+$ groups had a decreased body weight compared to EC and $\mathrm{OO}$ groups $(\mathrm{p}<0.001)$ (Table 1 and Figure1).

TABLE 1 - BW (mg), expressed in means and SD, on the four analyzed GD

\begin{tabular}{|c|c|c|c|c|}
\hline & $\mathrm{EC}$ & $\mathrm{OO}$ & $\mathrm{N}-$ & $\mathrm{N}+$ \\
\hline 18.5 & $2361( \pm 193)^{\sharp c, d}$ & $2603( \pm 280)^{*} \mathrm{c}, \mathrm{d}$ & $3080( \pm 751)$ & $3094( \pm 66)$ \\
\hline 19.5 & $4377( \pm 218)^{\sharp c, d}$ & $4285( \pm 333)^{\# c, d}$ & $3205( \pm 676)$ & $3237( \pm 144)$ \\
\hline 20.5 & $5031( \pm 417)^{* \mathrm{c}, \# \mathrm{~d}}$ & $5148( \pm 291)^{\# c, d}$ & $4582( \pm 564)^{* d}$ & $4073( \pm 85)$ \\
\hline 21.5 & $7069( \pm 225)^{\# \mathrm{c}, \mathrm{d}}$ & $6738( \pm 300)^{\# \mathrm{c}, \mathrm{d}}$ & $5462( \pm 613)$ & $5458( \pm 193)$ \\
\hline
\end{tabular}

EC: External control; OO: Olive oil control, N-: Nitrofen without CDH; $\mathrm{N}+$ : Nitrofen with $\mathrm{CDH}$; BW: Body weight.

${ }^{*} \mathrm{p}<0.05 ; \# \mathrm{p}<0.001$; ${ }^{\mathrm{a} C o m p a r e d}$ with EC group, ${ }^{\mathrm{b} C o m p a r e d ~ w i t h ~ O O ~ g r o u p, ~}$ ${ }^{\mathrm{c} C o m p a r e d}$ with $\mathrm{N}$ - group, ${ }^{\mathrm{d} C o m p a r e d}$ with $\mathrm{N}+$ group.

\section{Diaphragm area $(D A)$}

There was a progressive increase of DA in all groups, but it was attenuated in fetuses that received nitrofen in comparison to EC and OO fetuses. DA was statistically lower in fetuses exposed to nitrofen with or without $\mathrm{CDH}$ than in control and placebo groups $(\mathrm{p}<0.001)$ (Table 2 and Figure 1$)$.

TABLE 2 - DA $\left(\mathrm{mm}^{2}\right)$, expressed in means and SD, on the four analyzed GD.

\begin{tabular}{|c|c|c|c|c|c|c|c|}
\hline & $\mathrm{EC}$ & & $\mathrm{OO}$ & & N- & & $\mathrm{N}+$ \\
\hline 18.5 & $42.22( \pm 7.16)$ & $\# \mathrm{c}$ & $43.12( \pm 6.09)$ & ${ }_{\mathrm{c},{ }^{\mathrm{d}} \mathrm{d}}$ & $33.46( \pm 0.81)$ & & $37.35( \pm 0.86)$ \\
\hline 19.5 & $70.72( \pm 5.41)$ & $\# \mathrm{c}, \mathrm{d}$ & $71.90( \pm 6.10)$ & ${ }_{H c, d}$ & $45.45( \pm 12.36)$ & & $43.62( \pm 3.70)$ \\
\hline 20.5 & $83.63( \pm 8.52)$ & $\# c, \mathrm{~d}$ & $80.99( \pm 6.43)$ & $\# c, \mathrm{~d}$ & $47.51( \pm 8.93)$ & $*_{\mathrm{d}}$ & $56.61( \pm 8.84)$ \\
\hline 21.5 & $97.33( \pm 7.87)$ & $\# \mathrm{c}, \mathrm{d}$ & $95.72( \pm 6.49)$ & $\#,, \mathrm{~d}$ & $63.80( \pm 8.93)$ & & $64.00( \pm 7.03)$ \\
\hline
\end{tabular}

EC: External control; OO: Olive oil control; N-: Nitrofen without $\mathrm{CDH}$; $\mathrm{N}+$ : Nitrofen with CDH; DA: Diaphragm area.

${ }^{*} \mathrm{p}<0.05$; \# $<0.001 ;{ }^{\mathrm{a}}$ Compared with EC group, ${ }^{\mathrm{b}}$ Compared with OO group, ${ }^{\mathrm{c} C}$ Compared with $\mathrm{N}$ - group, ${ }^{\mathrm{d}}$ Compared with $\mathrm{N}+$ group.

\section{Diaphragmatic hernia area}

On $\mathrm{N}+$ group, the hernia area increased progressively with the progress of gestation with difference in HA on day 18.5 compared with day $21.5(\mathrm{p}<0.05)$. However, there was no statistical change in the ratio HA/DA ( $p>0.05$ ) (Table 3 and Figures 1-2). 
TABLE 3 - HA $\left(\mathrm{mm}^{2}\right)$ and HA/DA, expressed in means and SD on the four analyzed GD.

\begin{tabular}{lccc}
\hline & HA & & HA/DA \\
\cline { 4 - 4 } 18.5 & $9.06( \pm 0.05)$ & & $0.250( \pm 0.017)$ \\
19.5 & $14.37( \pm 6.21)$ & & $0.328( \pm 0.030)$ \\
20.5 & $18.64( \pm 7.18)$ & & $0.323( \pm 0.086)$ \\
21.5 & $20.27( \pm 7.50)$ & $*$ & $0.323( \pm 0.131)$ \\
\hline
\end{tabular}

HA: Hernia area; HA/DA: hernia to total diaphragm area ratio. ${ }^{*} p<0.05$ compared with GD 18.5 .

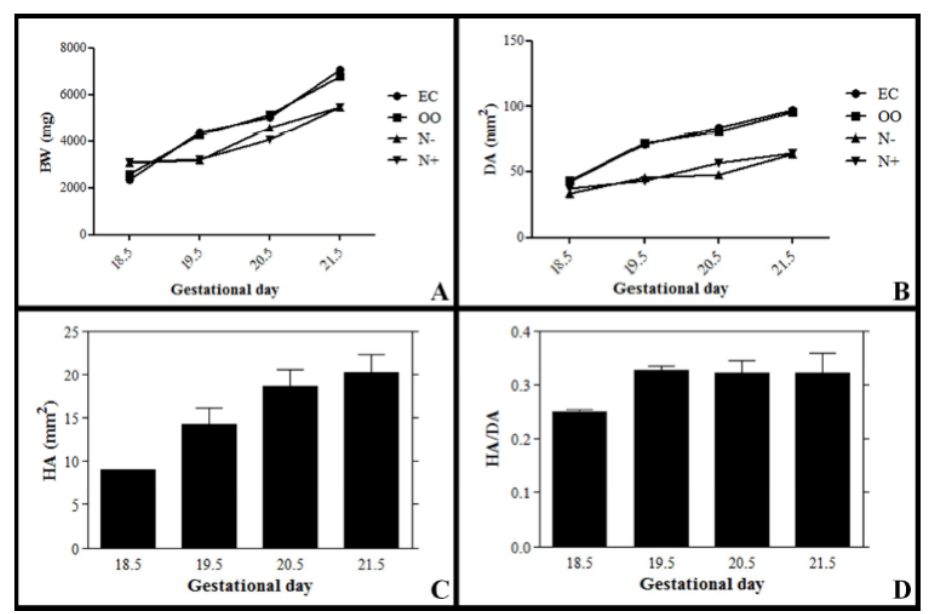

FIGURE 1 - Graphics of morphometrics results: BW (A), DA (B), HA (C), HA/DA (D).

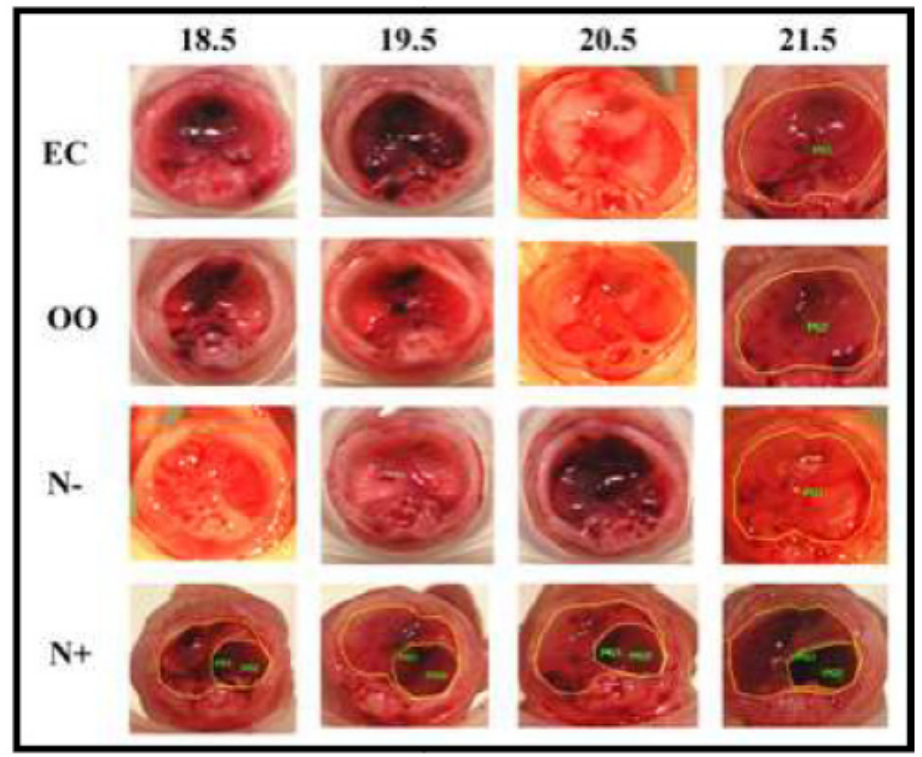

FIGURE 2 - Photographs of the diaphragm of EC, OO, N- and N+ groups on the four analyzed GD.

Histology showed no difference between groups (Figure 3 ), but immunohistochemistry showed that on groups exposed to nitrofen, the intensity for myosin staining was weaker (Figure 4).

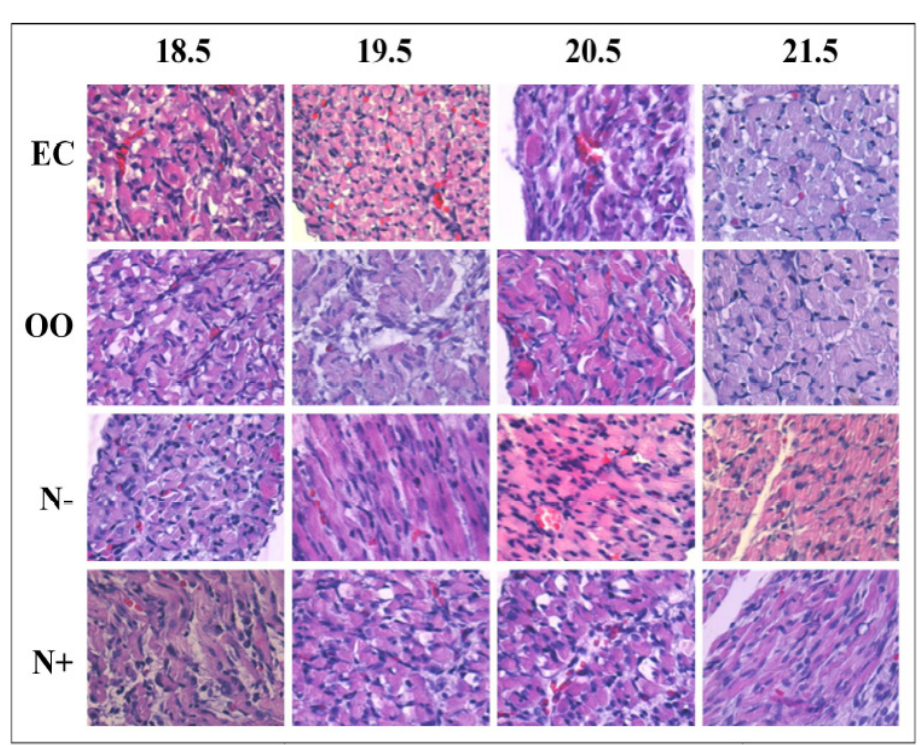

FIGURE 3 - Photomicrographs of diaphragm stained with H/E of the four studied groups $(\mathrm{EC}, \mathrm{OO}, \mathrm{N}-$ and $\mathrm{N}+$ ) on the four analyzed GD.

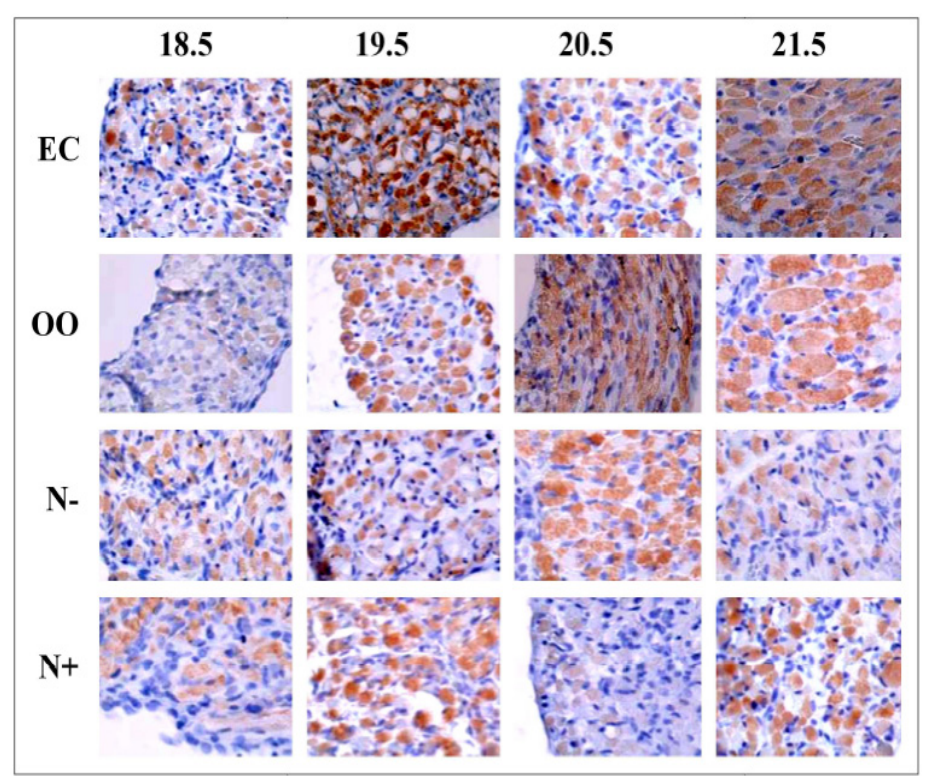

FIGURE 4 - Immunohistochemistry for myosin of the four studied groups $(\mathrm{EC}, \mathrm{OO}, \mathrm{N}-$ and $\mathrm{N}+$ ) on the four analyzed GD.

\section{Discussion}

The CDH model induced by nitrofen in fetal rats has been widely used to investigate the pathogenesis of diaphragmatic defect and other associated malformations similarly to humans ${ }^{8,10}$.

In our study fetuses exposed to nitrofen with and without $\mathrm{CDH}$ had their final BW decreased $(\mathrm{p}<0.001)$, results that are similar to the ones of Schmidt et al. $(2010)^{8}$. The area of the hernia steadily increased between the analyzed ages, while the HA/DA ratio remaining stable even though the abdominal organs had filled the thoracic space.

The posthepatic mesenchymal plate (PHMP), an 
embryological structure responsible for the development of diaphragm muscle, is damaged in nitrofen induced $\mathrm{CDH}$ model, leading to the formation of the gap ${ }^{11}$. When the defect is on the left side, the chest may contain small and large intestine, spleen, stomach, left lobe of the liver and, rarely, the kidney. The right side $\mathrm{CDH}$ can contain the right lobe of the liver and sometimes the bowel and/or kidney ${ }^{12}$. In our study, the majority of hernias were present on the left side, with the left lobe of the liver invading the chest. This happens due to a later closure of pleuroperitoneal canal on the left side ${ }^{4}$.

Although Babiuk and Greer postulate that the defect on the diaphragm occurs independently of myogenesis ${ }^{13}$, Jens et al. have found that the gene of a myogenic differentiation 1 (MyoD) plays an important role on formation of muscle fibers during the development of the diaphragm. This gene is expressed in the precursors muscle cells and may interfere in its migration and proliferation $^{10}$

In spite of the fact that formation of diaphragm muscle fibers in fetal rats is terminated by 22 days of gestation ${ }^{10}$, the histological analysis showed no difference in arrangement of diaphragmatic muscle fibers on any of the ages and groups, even in fetuses exposed to nitrofen.

The diaphragm, as a striated muscle, is characterized by sarcomeres containing actin and myosin. In humans, it contains four myosin isoforms of heavy chains and six of light chains ${ }^{14}$. The antibody used on immunohistochemistry recognizes myosin, specifically fast-twitch molecules (type II) of myosin's heavy chain.

Our results showed a decrease on labeling of myosin's fast fibers in the diaphragms exposed to nitrofen. In normal fetuses the diaphragm is different from other skeletal muscles by having an early transition of myosin's slow fibers to fast fibers, an essential phenomenon for the diaphragm to perform efficient and fast contractions and with a high threshold for fatigue at birth ${ }^{15}$.

There are no reports in the literature on the proportion of fast myosin fibers in $\mathrm{CDH}$, though a late transition could worsen the respiratory failure observed in these neonates due to fatigue of slow fibers compared to the fast ones. This would have particular relevance in the first minutes of life of newborns and at the time of ventilatory support withdrawal ${ }^{15}$. In a pathological situation, several factors can influence the composition of the diaphragm and the result, in terms of adaptation, of the slow and fast fibers is difficult to predict ${ }^{14}$.

The decreased expression of myosin on the diaphragm in fetuses exposed to nitrofen may reflect the direct action of the herbicide in the development of the muscle or be an indirect expression of decreased migration of myocytes to form the muscular diaphragm.

Despite of progress in prenatal diagnosis and in understanding on the development of normal diaphragm, the $\mathrm{CDH}$ is poorly studied with regard to embryology and biochemistry of the diaphragm. Thus, a more detailed study might clarify molecular and genetic mechanisms underlying the defect of the diaphragm in $\mathrm{CDH}^{10,11}$.

\section{Conclusions}

Hernia area remains constant in the three intermediate stages of lung development with less immunostaining of myosin on the diaphragm exposed to the drug. These results motivate an investigation of the mechanism of action of myosin on the earliest stage (embryonic) of the development of diaphragm and its implications in the pathogenesis of the disease.

\section{References}

1. Greer JJ, Cote D, Allan DW, Zhang W, Babiuk RP, Ly L, Lemke $\mathrm{RP}$, Bagnall K. Structure of the primordial diaphragm and defects associated with nitrofen-induced CDH. J Appl Physiol. 2000;89:2123-9.

2. Allan DW, Greer JJ. Pathogenesis of nitrofen-induced congenital diaphragmatic hernia in fetal rats. J Appl Physiol. 1997;83:338-47.

3. Stege G, Fenton A, Jaffray B. Nihilism in the 1990s: the true mortality of congenital diafragmatic hernia. Pediatrics. 2003;112:532-5.

4. Tannuri U. Heart hypoplasia in an animal model of congenital diaphragmatic hernia. Rev Hosp Clin Fac Med Sao Paulo. 2001;56:173-8.

5. Allan DW, Greer JJ. Polysialylated NCAM expression during motor axon outgrowth and myogenesis in the fetal rat. J Comp Neurol. 1998;391:275-92.

6. Brotto MA, Biesiadecki BJ, Brotto LS, Nosek TM, Jin JP. Coupled expression of troponin $\mathrm{T}$ and troponin I isoforms in single skeletal muscle fibers correlates with contractility. Am J Physiol Cell Physiol. 2006;290:C567-76.

7. Andersen DH. Incidence of congenital diaphragmatic in the young of rats bred on a diet deficient in vitamin A. AM J Dis Child. 1941;62:888-9.

8. Schmidt AF, Gonçalves FL, Nassr AC, Pereira LA, Farmer D, Sbragia L. Antenatal steroid and tracheal occlusion restore vascular endothelial grouth factor receptors in congenital diaphragmatic hernia rat model. Am J Obstet Gynecol. 2010;203:184.e13-20.

9. Clugston RD, Zhang W, Greer JJ. Early development of the primordial mammalian diaphragm and cellular mechanisms of nitrofen-induced congenital diaphragmatic hernia. Birth Defects Res A Clin Mol Teratol. 2010;88:15-24.

10. Dingemann J, Doi T, Ruttenstock E, Puri P. The role of primary myogenic regulatory factors in the developing diaphragmatic muscle in the nitrofen-induced diaphragmatic hernia. Pediatr Surg Int. 2011.27:579-82.

11. Mayer S, Metzger R, Kluth D. The embryology of the diaphragm. Semin Pediatr Surg. 2011;20:161-9.

12. Tovar JA. Congenital diaphragmatic hernia. Orphanet J Rare Dis. 
2012;7:1.

13. Babiuk RP, Greer JJ. Diaphragm defects occur in a $\mathrm{CDH}$ hernia model independently of myogenesis and lung formation. Am J Physiol Lung Cell Mol Physiol. 2002;283:1310-4.

14. Gayan-ramirez G, Decramer M. Clinical relevance of myosin isoforms in the diaphragm. Rev Mal Respir. 2000;17:574-84.

15. Kelly AM, Rosser BW, Hoffman R, Panettieri RA, Schiaffino S, Rubinstein NA, Nemeth PM. Metabolic and contractile protein expression in developing rat diaphragm muscle. J Neurosci. $1991 ; 11: 1231-42$.

\section{Correspondence:}

Lourenço Sbragia

Laboratório de Cirurgia Fetal Experimental "Michael R Harrison"

Departamento de Cirurgia e Anatomia

Faculdade de Medicina de Ribeirão Preto-USP

Avenida Bandeirantes, 3900

14048-900 Ribeirão Preto - SP Brasil

Tel.: (55 16)3602-2593

Fax: +55-16-3633-0836

sbragia@fmrp.usp.br

Conflict of interest: none

Financial source: FAPESP - Sao Paulo Research Foundation - Research Grant \#11/00794-1 and Scholarship \#11/12587-0.

${ }^{1}$ Research performed at Laboratory of Experimental Fetal Surgery School of Medicine of Ribeirao Preto, University of Sao Paulo - USP, Ribeirao Preto - SP, Brazil. 